\title{
Corporate Social Responsibility Agreements Model for Community Development: The Case of Golden Star (Bogoso/Prestea) Limited and its Mine Local Community*
}

\author{
D. Mireku-Gyimah and R. Gyamfi
}

Mireku-Gyimah, D. and Gyamfi R. (2016), "Corporate Social Responsibility Agreements Model for Community Development: The Case of Golden Star (Bogoso/Prestea) Limited and its Mine Local Community", Ghana Mining Journal, Vol. 16, No. 1, pp. 96 - 105.

\begin{abstract}
In Ghana, community development is regarded by mine local communities as the most important aspect of Corporate Social Responsibility (CSR), to the extent that often community development is perceived to be a statutory responsibility of mining companies. Consequently, mine local communities demand for more and more, sometimes prohibitively expensive, contributions towards community development. The inability of mining companies to meet all the demands often leads to unsavoury relation between mining companies and their host communities with concomitant adverse effect on mining operations. This constitutes a business risk that needs to be addressed properly by shifting from the earlier practices of making voluntary contributions towards community development to making sustainable community development an integral part of the mining business. This paper presents the evolutionary strategic models, with differing principles and action plans, used by Golden Star (Bogoso/Prestea) Limited (GSBPL) over the years to manage the development of its Bogoso/Prestea Mine Local Community (BPMLC), videlicet from a poor Philanthropic Community Assistance Model (PCAM) to an improved but ineffective Community Driven Assistance Model (CDAM) and eventually to the current effective, successful CSR Agreements Model (CSRAM). The paper also highlights the lessons learnt from the negotiation process that led to formulation of the CSRAM as well as the benefits and successes resulting from its implementation and the challenges. It is concluded that mutual understanding, tolerance, transparency, trust, commitment and accountability are key to the successful management of CSR and community development.
\end{abstract}

Keywords: Social Responsibility, Agreements Model, Mining Communities

\section{Introduction}

Mining companies regard community development as an aspect of Corporate Social Responsibility (CSR) and therefore manage it differently as per the various definitions of CSR: as voluntary, charitable, philanthropic donations (Freeman and Liedtka, 1991; Baker, 2010); as ways and means of getting social license to operate (Wood, 1991; Gray et al., 1996; Hilson, 2006) as commitment to the improvement of the socio-economic life of the local community and other stakeholders (Davis, 1960; Holme and Watts, 2000); and as obligatory partnership with the local community for mutual benefits (Hamil, 1999; Eshun and Mireku-Gyimah, 2012). Until there are laws to regulate CSR, mining companies will continue to manage CSR differently. However, irrespective of the principle and approach used to manage CRS, the cardinal interest of mine local communities is the benefits they get from mining operations.

In Ghana, community development is regarded by mine local communities as the most important aspect of Corporate Social Responsibility (CSR), to the extent that often community development is perceived to be a statutory responsibility of mining companies. Consequently, mine local communities demand for more and more, sometimes prohibitively expensive, contributions towards community development. The inability of mining companies to meet all the demands often leads to unsavoury relation between mining companies and their host communities with concomitant adverse effect on mining operations. This constitutes a business risk that needs to be addressed properly by shifting from the earlier practices of making voluntary contributions towards community development to making sustainable community development an integral part of the mining business. The subject of this paper is to present how this shift by Golden Star (Bogoso/Prestea) Limited (GSBPL) has improved its relation with its mine local community, the Bogoso/Prestea Mine Local Community (BPMLC).

GSBPL operates a series of open pits and two processing plants located near the towns of Bogoso and Prestea in the Western Region of Ghana. GSBPL has three mining leases, namely: the Bogoso Mining Lease, Prestea Mining Lease and Pampe Mining Lease. Each mining lease has a number of community towns located in it (see Table 1). Each community town has a number of settlements. Each community town and its settlements constitute a catchment area (see Table $2 \mathrm{a}, 2 \mathrm{~b}$ and $2 \mathrm{c}$ ). The BPMLC consists of all the catchment areas. As can be seen, the BPMLC is 
complex and therefore poses complex CSR issues, especially community development.

Table 1 Mining Leases and Towns

\begin{tabular}{|c|c|c|}
$\begin{array}{c}\text { Towns in } \\
\text { Bogoso Mining } \\
\text { Lease }\end{array}$ & $\begin{array}{c}\text { Towns in } \\
\text { Prestea } \\
\text { Mining } \\
\text { Lease }\end{array}$ & $\begin{array}{c}\text { Towns in } \\
\text { Pampe } \\
\text { Mining } \\
\text { Lease }\end{array}$ \\
\hline Bogoso & Prestea & Adaamanso \\
\hline Dumasi & Himan & Ehyireso \\
\hline Boppoh & Bondaye & \\
\hline & $\begin{array}{c}\text { Mbease } \\
\text { Nuta }\end{array}$ \\
& \multicolumn{2}{|c}{} \\
\end{tabular}

Table 2a Mining Lease, Catchment Areas and Settlements

\begin{tabular}{|c|l|l|l||}
\hline $\begin{array}{c}\text { Mining } \\
\text { Lease }\end{array}$ & \multicolumn{3}{|c|}{ Bogoso Mining Lease } \\
\hline $\begin{array}{c}\text { Catchment } \\
\text { Areas }\end{array}$ & \multicolumn{1}{|c|}{ Bogoso } & Dumasi & \multicolumn{1}{|c|}{ Boppoh } \\
\hline & Adjeikrom & Dumasi & Boppoh \\
& Akokobedia- & Juaben & Township \\
& brow & Brakwa & Ankomanyin- \\
& Bogoso & Line & krom \\
& Esikafo & Twegya & Apeatse \\
& Amba- Ntem & & Boppoh \\
Settlements & Atobrakrom & & Kobrim \\
& Yebedanegya & & Boppoh \\
& Atekyem & & Kokwaado \\
& Kokoase & & Boppoh \\
& & & Nkuntunso \\
& & Krobo Line \\
& & Kumsuno \\
\hline
\end{tabular}

Table 2b Mining Lease, Catchment Areas and Settlements

\begin{tabular}{|c|c|c|c|}
\hline \multicolumn{4}{|c|}{ Prestea Mining Lease } \\
\hline Prestea & Himan & Bondaye & $\begin{array}{c}\text { Mbease } \\
\text { Nsuta }\end{array}$ \\
\hline $\begin{array}{l}\text { A Compound } \\
\text { Aketewa } \\
\text { Anfagya } \\
\text { Anwiam } \\
\text { Boiler Site } \\
\text { Broadcasting } \\
\text { Area } \\
\text { Brumase } \\
\text { Dagarti- } \\
\text { Compound } \\
\text { Kroo Town- } \\
\text { East/West } \\
\text { Kroo Town - } \\
\text { Nakaba } \\
\text { Kwame- } \\
\text { Niampa } \\
\text { Mankessim } \\
\text { Market- } \\
\text { Square } \\
\text { Nakaba } \\
\text { No.3D- } \\
\text { Compound } \\
\text { Nsuekyir } \\
\text { Roman Hill } \\
\text { Top Hill }\end{array}$ & $\begin{array}{l}\text { Himan } \\
\text { Ankobra } \\
\text { Ahenebo- } \\
\text { boano } \\
\text { Akromanto } \\
\text { Bantima } \\
\text { Sikafoamba- } \\
\text { ntem }\end{array}$ & $\begin{array}{l}\text { Barracks- } \\
\text { (Lowcost) } \\
\text { Cemetery- } \\
\text { Road } \\
\text { New- } \\
\text { Compound } \\
\text { Sedumase } \\
\text { Sedumase- } \\
\text { Chapel } \\
\text { Sedumase- } \\
\text { Zongo }\end{array}$ & $\begin{array}{l}\text { Bawua Akura } \\
\text { Mbease Nsuta } \\
\text { Nsuta- } \\
\text { Mantem } \\
\text { Godday } \\
\text { Nsuta- } \\
\text { Nyamebe- } \\
\text { kyere } \\
\text { Nsuta- } \\
\text { Bowohomo- } \\
\text { den }\end{array}$ \\
\hline
\end{tabular}

Table 2c Mining Lease, Catchment Areas and Settlements

\begin{tabular}{||l|l||}
\hline \multicolumn{2}{|c||}{ Pampe Mining Lease } \\
\hline Adaamanso & \multicolumn{1}{c|}{ Ehyireso } \\
\hline Adaamanso & Ehyireso \\
Somanya & Ehyireso Akromanto \\
Odisikakrom & \\
Bontoary & \\
Bonsubonsuho & \\
\hline
\end{tabular}

In addressing the complex issues, community development by GSBPL, as part of its CSR, has gone through three phases of evolution over years, using the following models:

Phase 1: Philanthropic Community Assistance Model (2001 -2006);

Phase 2: Community Driven Assistance Model (2006 - 2012); and

Phase 3: Corporate Social Responsibility Agreements Model (2012 - date).

\subsection{Philanthropic Community Assistance Model (PCAM)}

Right from the beginning of its mining operation in 2001, GSBPL recognised that the cooperation of its host community, the BPMLC, was necessary for good mining business and therefore made proactive community relations and stakeholder engagement an integral part of its mining strategy. A major action plan of the strategy was the provision of philanthropic assistance to the socio-economic development of the BPMLC. From 2001 to late 2006, GSBPL, unarguably, provided some good philanthropic assistance towards the development of the BPMLC such as provision of potable borehole water, a health clinic and financial support for education. Interested people from the BPMLC were encouraged to participate in an Alternative Livelihood Programme (ALP) introduced by GSBPL. Participants in the ALP were trained and resourced to engage in poultry farming, production of batik, tye\&die, soap and creams. A major aspect of the ALP was the Smallholder Oil Palm Out-Grower Scheme whereby selected individual farmers in the BPMLC were provided with oil palm seedlings, fertilizer, wellington boots and cutlasses to effectively engage in oil palm farming.

Unfortunately, all the community development projects during this period were based on GSBPL's perceived needs of the BPMLC and which catchment area needed attention. No rigorous assessment and consultations with the BPMLC to ascertain its needs and interests were made. Consequently, although GSBPL had good intentions and implemented some community development projects, the BPMLC neither appreciated nor assumed ownership of the projects 
and some members of BPMLC continually expressed dissatisfaction of 'unfair' distribution of the projects among the catchment areas. In the end, GSBPL realised that people in the BPMLC were not patronising the community development programmes and the completed projects were neither being effectively utilised nor maintained as expected. The failure of the philanthropic community development initiatives to satisfy BPMLC precipitated the need for a change from the PCAM to a Community Driven Assistance Model (CDAM).

\subsection{Community Driven Assistance Model (CDAM)}

Towards the end of 2006, GSBPL shifted from the PCAM to the CDAM. The aim of the CDAM was to involve BPMLC in the selection of community development projects and their locations. In this way, it was expected that BPMLC would appreciate the efforts of GSBPL, assume ownership of community development projects and so utilise them effectively and maintain them properly. For each catchment area, a Community Consultative Committee (CCC) comprising the Sub-Chief, Assembly Member(s), Women Group Representative and Youth Group Leader was constituted. The CCC was mandated to organise meetings to discuss the needs of the catchment area, prioritise and select development projects and present proposals thereof to the Community-Mine Consultative Committee (CMCC). The CCMC comprised Divisional Chiefs, Sub-Chiefs, Member of Parliament, District Chief Executive, Assembly Members, Area Council Chairmen, Youth Group Leaders and some GSBPL personnel. The CMCC's mandate was to review all project proposals from the CCC and recommend them for funding by GSBPL. To streamline the funding process, GSBPL established the Golden Star Development Foundation (GSDF) and made a yearly allocation of one dollar per ounce of gold sold and $0.1 \%$ of pretax profit into the GSDF. The Board of Trustees (BoT) of the GSDF, comprising only GSBPL personnel, was mandated to manage the funds of the GSDF and, depending on the availability of funds, approve projects recommended by the CMCC and make payments for their execution.

Refreshingly, the CDAM resulted in the completion of a number of community development projects including the following:

(i) Health Facilities: Prestea Outpatient Department, Bogoso Nurses Quarters, Project Cure

(ii) Education Facilities: Adaamanso DA School, Juabeng School, Prestea Secondary Technical School (iii) Water and Sanitation: Boreholes for Prestea and Bogoso, Toilets for Dumasi and Bogoso Police Station

(iv) Social Centre Buildings: Centres for Chujah, Kwame Niampa and Bondaye

As part of the CDAM, the Golden Star Community Educational Scholarship Scheme (GSCESS) was also established to provide financial support to brilliant but needy children to enable them study at secondary and tertiary educational institutions. The Smallholder Oil Palm Out-Grower Scheme in the PCAM that provided support to individual farmers was replaced with the Golden Star Oil Palm Plantation (GSOPP) project in which interested individual farmers could participate. GSBPL also made a separate yearly allocation of one dollar per ounce of gold sold to fund the GSOPP and partnered with Benso Oil Palm Plantation Limited (BOPP) to provide technical assistance to the farmers and also purchase the oil palm fruits produced from the GSOPP.

The CDAM appeared to be successful. The BPMLC appeared to be happy with the projects but some disgruntled vociferous individuals in the BPMLC, especially in the Himan and Prestea catchment areas, incessantly accused GSBPL of neglecting community development and spearheaded agitations to go on protest demonstrations which sometimes disrupted mining operations and brought about confrontations between the demonstrators and the police. Of particular concern were the resistance to the Prestea South Mbease Nsuta Open Pit Project, which stalled the start of the project for over 4 years, and the unreasonable demand that GSBPL re-opens the Prestea Underground Mine at any cost before it would be allowed to develop the Prestea South Mbaese Nsuta Open Pit Project. Thus although the CDAM appeared to be successful, it could not secure the cooperation and 'social license' of the BPMLC that GSBPL needed to operate peacefully, a situation that necessitated the change of the CDAM.

\section{Resources and Methods Used}

\subsection{The Mediation Committee}

After extensive deliberation and consultation with the Paramount Chief of Wassa Fiase Traditional Council (the overlord of BPMLC) on how to resolve the deteriorating relation between the two Parties, GSBPL and BPMLC, especially regarding how to overcome the persistent social resistance to the Prestea South Mbease Nsuta Open Pit Project, GSBPL, decided to initiate discussion and negotiation with representatives of BPMLC and other stakeholders. Consequently, towards the end of 2010, a Mediation Committee comprising 
representatives of BPMLC on the one part and representatives of GSBPL on the other part was constituted. The two Parties decided to appoint an independent Moderator to chair the Mediation Committee. The Parties also appointed a Comoderator to assist the Moderator.

\subsection{The Negotiation Process and Outcomes}

Fig. 1 illustrates the negotiation process and outcomes. The negotiation process involved extensive deliberations, consultations and negotiations between the two Parties at 24 meetings lasting over two years. During this period, the Moderator organised durbars in all the 9 catchment areas to interact with the inhabitants on the objectives of the negotiation and solicit their inputs. The Moderator also interacted with other stakeholders such as the Minerals Commission, Environmental Protection Agency, Police and civil society to solicit their inputs. During the interactions, it became apparent that both Parties had concerns and had lost confidence in, and mistrusted, each other. BPMLC's concerns were that GSBPL was not transparent; did not honour promises; disrespected cultural values; employed very few people from the BPMLC; and gave very little support to, and preferentially funded community development projects. GSBPL's concerns were that BPMLC was uncooperative and intolerant; was ungrateful in spite of enjoying completed community development projects; and was prone to making excessive demands, the cost of which could not be absorbed. It was, however, clear that both Parties were prepared and willing to deliberate on the concerns of each other and work together for mutual benefits. Both Parties also realised the need to be transparent and tolerant in the deliberations so that they could understand each other's problems; agree on each other's commitments and responsibilities and how to relate to each other; and work out modalities for working together for mutual benefits. Consequently, at the end of the extensive deliberations, consultations and negotiations, the outcomes were formulated in three CSR Agreements' documents, namely:

(i) Relationship and Sustainable Livelihood Agreement;

(ii) Local Employment Agreement; and

(iii) Development Foundation Agreement.

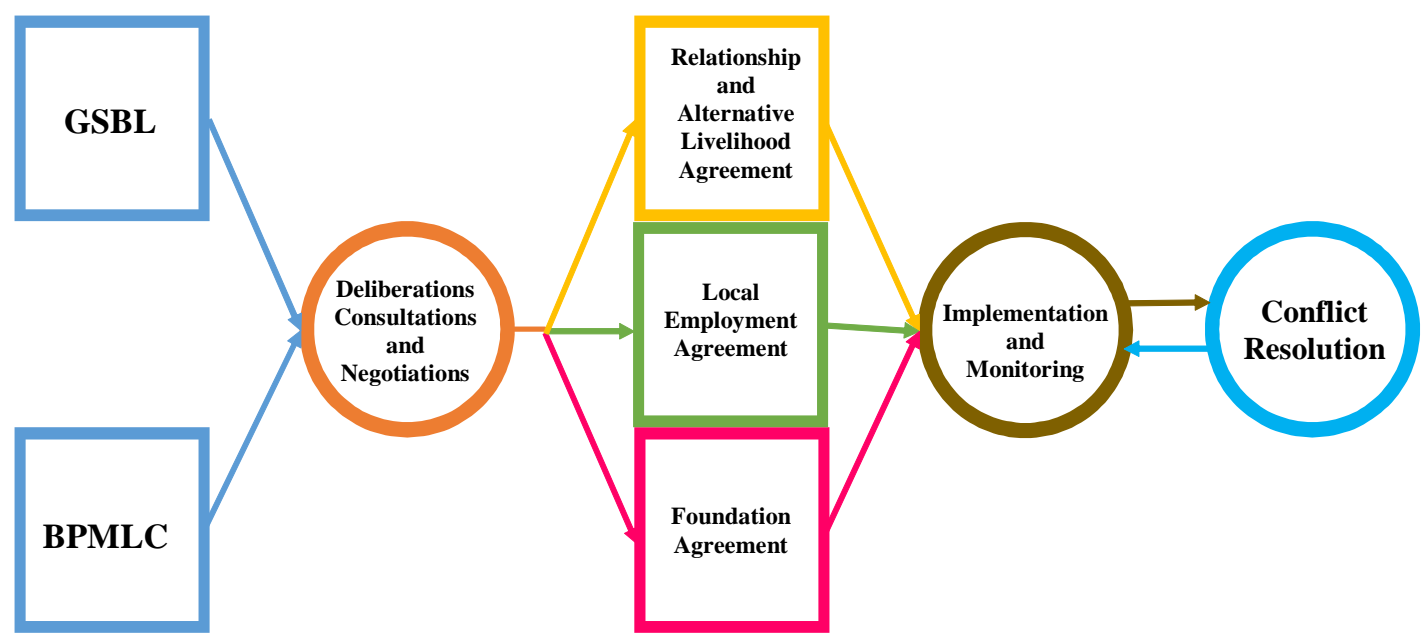

Fig. 1 Negotiation Process and Outcomes (adopted from Mireku-Gyimah, 2013) 


\section{Results and Discussion}

\subsection{The Relationship and Alternative Livelihood Agreement (RALA)}

The RALA spells out the cardinal mutual understanding between the two Parties as follows:

(i) The Parties agree that the Company needs to undertake its mining operations within its mining leases in a peaceful atmosphere.

(ii) The Parties agree that the Community needs sustainable livelihood and socioeconomic development.

(iii) The Company shall be committed to promoting sustainable socio-economic development within the Community.

(iv) The Community shall be committed to discussions and consultations with the Company on issues of mutual interest and promote peace and harmony between the Company and Community.

(v) The Parties further agree to abide by the principles of openness and sharing of information that will enable them understand each other's perspectives on issues of mutual interest.

(vi) The Parties also agree to maintain trust, sustain good working relations and resolve

(viii) Streamline and make an agreement for the establishment and management of a foundation to be called "Golden Star (Bogoso/Prestea) Development Foundation", which shall be the main vehicle through which the Parties shall achieve sustainable socio-economic development of the Community.

(ix) Make an agreement ("Local Employment Agreement") to streamline procedures for the employment of people or indigenes within the Community.

(x) Procure or ensure, through separate agreements, the inclusion of the Community in the activities of the Golden Star Oil Palm Plantations Ltd. (GSOPP).

The RALA stipulates the specific roles that the Chiefs, Community and its citizens, Company and its employees and the District Assembly must play to maintain transparency, peace and harmony between the two Parties. Procedures for information and communication management, environmental and social participatory management, land use management and conflict resolution are all spelt out. challenges and conflicts through discussions and negotiations based on tolerance and patience.

The RALA also spells out the following aims that cover all the three CSR Agreements:

(i) Provide a clear, transparent and explicit statement of the commitments of both Parties.

(ii) Provide the Community with the opportunity to participate in the company's decisions and plans that may affect the Community.

(iii) Build strong communication ties between the Parties.

(iv) Set out the key principles and directions on how the Parties will work together for mutual benefits.

(v) Define key issues that the Parties need to address.

(vi) Ensure the promotion of sustainable development within the Community.

(vii) Provide for the establishment of identifiable bodies and organs, including a Mediation Committee, to deliberate on issues of mutual interest and to oversee the implementation of the agreements.

A highlight of the RALA is the simplification and fomalisation of the processes and modalities by which members of BPMLC participate in the GSOPP, which is an alternative livelihood project.

\subsection{The Local Employment Agreement (LEA)}

The LEA defines transparent policies, procedures and modalities for the employment of people in the BPMLC by GSBPL and commits both Parties to respect the terms and conditions in the LEA. For equitable distribution of employment among the catchment areas, the population, total land size in the mining leases and land size in the active mining area of each catchment area as well as the commitment of each catchment area to the CSR Agreements were used to derive a formula for sharing employment opportunities among the catchment areas in any mining lease (MirekuGyimah, 2012). Tables $3 \mathrm{a}$ and $3 \mathrm{~b}, 4 \mathrm{a}$ and $4 \mathrm{~b}$, and $5 \mathrm{a}$ and $5 \mathrm{~b}$ show how employment opportunities are shared among catchment areas in each of the three mining leases of GSBPL. 
Table 3a Prestea Mining Lease - Factors for Sharing Employment

\begin{tabular}{|l|c|r|r|r|r|c||}
\hline \multicolumn{1}{|c|}{ Criteria } & \multicolumn{2}{|c|}{ Population } & \multicolumn{2}{c|}{ Mining Concession } & \multicolumn{2}{c||}{ Active Mining Area } \\
\hline $\begin{array}{c}\text { Catchment } \\
\text { Area }\end{array}$ & Size & Factor & Size & Factor & Size & Factor \\
\hline Prestea & 38390 & 0.65 & 6.36 & 0.07 & 1.05 & 0.04 \\
\hline Himan & 17074 & 0.29 & 19.8 & 0.22 & 9.19 & 0.37 \\
\hline Bondaye & 1923 & 0.03 & 26.87 & 0.30 & 7.07 & 0.28 \\
\hline Mbease Nsuta & 1262 & 0.02 & 37.47 & 0.41 & 7.78 & 0.31 \\
\hline Total & $\mathbf{5 8 6 4 9}$ & $\mathbf{1 . 0 0}$ & $\mathbf{9 0 . 5}$ & $\mathbf{1 . 0 0}$ & $\mathbf{2 5 . 0 9}$ & $\mathbf{1 . 0 0}$ \\
\hline \hline
\end{tabular}

Table 3b Prestea Mining Lease - Sharing of Employment (per 100 vacancies)

\begin{tabular}{|c|c|c|c|c|c|c|}
\hline Percentage & $10 \%$ & $15 \%$ & $20 \%$ & $45 \%$ & $10 \%$ & \\
\hline $\begin{array}{c}\text { Catchment } \\
\text { Area }\end{array}$ & $\begin{array}{l}\text { Shared } \\
\text { Equally }\end{array}$ & $\begin{array}{l}\text { Shared by } \\
\text { Population }\end{array}$ & $\begin{array}{l}\text { Shared by } \\
\text { Concession }\end{array}$ & $\begin{array}{l}\text { Shared by } \\
\text { Activities }\end{array}$ & $\begin{array}{c}\text { Shared by } \\
\text { Commitment }\end{array}$ & Total \\
\hline Prestea & 2.5 & 9.8 & 1.4 & 1.88 & 2.5 & 18 \\
\hline Himan & 2.5 & 4.4 & 4.4 & 16.48 & 2.5 & 30 \\
\hline Bondaye & 2.5 & 0.5 & 5.9 & 12.68 & 2.5 & 24 \\
\hline Mbease Nsuta & 2.5 & 0.3 & 8.3 & 13.95 & 2.5 & 28 \\
\hline Total & 10 & 15 & 20 & 45 & 10 & 100 \\
\hline
\end{tabular}

Table 4a Bogoso Mining Lease - Factors for Sharing Employment

\begin{tabular}{||c|c|l|r|r|r|c||}
\hline \multicolumn{1}{|c|}{ Criteria } & \multicolumn{2}{|c|}{ Population } & \multicolumn{2}{c|}{ Mining Concession } & \multicolumn{2}{c||}{ Active Mining Area } \\
\hline $\begin{array}{c}\text { Catchment } \\
\text { Area }\end{array}$ & Size & Factor & Size & Factor & Size & Factor \\
\hline Bogoso & 9819 & 0.54 & 43.62 & 0.48 & 19.03 & 0.49 \\
\hline Dumasi & 1571 & 0.09 & 18.7 & 0.21 & 12.12 & 0.31 \\
\hline Boppoh & 6938 & 0.38 & 28.55 & 0.31 & 7.79 & 0.20 \\
\hline Total & $\mathbf{1 8 3 2 8}$ & $\mathbf{1 . 0 0}$ & $\mathbf{9 0 . 8 7}$ & $\mathbf{1 . 0 0}$ & $\mathbf{3 8 . 9 4}$ & $\mathbf{1 . 0 0}$ \\
\hline \hline
\end{tabular}

Table 4b Bogoso Mining Lease - Sharing of Employment (per 100 vacancies)

\begin{tabular}{|c|c|c|c|c|c|c|}
\hline Percentage & $10 \%$ & $15 \%$ & $20 \%$ & $45 \%$ & $10 \%$ & \\
\hline $\begin{array}{c}\text { Catchment } \\
\text { Area }\end{array}$ & $\begin{array}{l}\text { Shared } \\
\text { Equally }\end{array}$ & $\begin{array}{l}\text { Shared by } \\
\text { Population }\end{array}$ & $\begin{array}{l}\text { Shared by } \\
\text { Concession }\end{array}$ & $\begin{array}{r}\text { Shared by } \\
\text { Activities }\end{array}$ & $\begin{array}{c}\text { Shared by } \\
\text { Commitment }\end{array}$ & Total \\
\hline Bogoso & 3.33 & 8.0 & 9.6 & 21.99 & 3.33 & 46 \\
\hline Dumasi & 3.33 & 1.3 & 4.1 & 14.01 & 3.33 & 26 \\
\hline Boppoh & 3.33 & 5.7 & 6.3 & 9.00 & 3.33 & 28 \\
\hline Total & 9.99 & 15 & 20 & 45 & 10 & 100 \\
\hline
\end{tabular}

Table 5a Pampe Mining Lease - Factors for Sharing Employment

\begin{tabular}{|l|c|c|c|l|r|c||}
\hline \multicolumn{1}{|c|}{ Criteria } & \multicolumn{2}{c|}{ Population } & Mining Concession & \multicolumn{2}{c|}{ Active Mining Area } \\
\hline Catchment Area & Size & Factor & Size & Factor & Size & Factor \\
\hline Adaamanso & 3784 & 0.67 & 9.15 & 0.69 & 5.31 & 1.00 \\
\hline Ehyireso & 1892 & 0.33 & 4.15 & 0.31 & 0 & 0.00 \\
\hline Total & $\mathbf{5 6 7 6}$ & $\mathbf{1 . 0 0}$ & $\mathbf{1 3 . 3 0}$ & $\mathbf{1 . 0 0}$ & $\mathbf{5 . 3 1}$ & $\mathbf{1 . 0 0}$ \\
\hline \hline
\end{tabular}


Table 5b Pampe Mining Lease - Sharing of Employment (per 100 vacancies)

\begin{tabular}{|l|c|c|c|c|c|c||}
\hline Percentage & $\mathbf{1 0 \%}$ & $\mathbf{1 5 \%}$ & $\mathbf{2 0 \%}$ & $\mathbf{4 5 \%}$ & $\mathbf{1 0 \%}$ & \multirow{2}{*}{ Total } \\
\cline { 1 - 1 } $\begin{array}{c}\text { Catchment } \\
\text { Area }\end{array}$ & $\begin{array}{c}\text { Shared } \\
\text { Equally }\end{array}$ & $\begin{array}{c}\text { Shared by } \\
\text { Population }\end{array}$ & $\begin{array}{c}\text { Shared by } \\
\text { Concession }\end{array}$ & $\begin{array}{c}\text { Shared by } \\
\text { Activities }\end{array}$ & $\begin{array}{c}\text { Shared by } \\
\text { Commitment }\end{array}$ & \\
\hline Adaamanso & 5 & 10 & 13.8 & 45.00 & 5.00 & 79 \\
\hline Ehyireso & 5 & 5 & 6.2 & 0.00 & 5.00 & 21 \\
\hline Total & $\mathbf{1 0}$ & $\mathbf{1 5}$ & $\mathbf{2 0}$ & $\mathbf{4 5}$ & $\mathbf{1 0}$ & $\mathbf{1 0 0}$ \\
\hline
\end{tabular}

The procedure for selecting people from prospective candidates for jobs was also devised. Jobs are categorised into those requiring skilled labour and those requiring unskilled labour. Whereas the employment of skilled labour is not restrictive to BPMLC, all unskilled labour must be from the BPMLC, preferably from the mining lease area where a job opportunity becomes available. As a rule, every prospective candidate from a catchment area must be validated to be a community citizen by the respective Assembly Member, Youth leader and Divisional Chief. For clarity and transparency, the citizen of a catchment area has been defined as follows:

(i) A person who hails from the catchment area;

(ii) A person whose father or mother hails from the catchment area;

(iii) A person who lives in the catchment area and has immovable property in the catchment area or its environs;

(iv) A person living in or outside the catchment area who is married to a person hailing from the catchment area; or

(v) A person who was born in the catchment area and has lived in the catchment area for at least 20 cumulative years.

The LEA also stipulates the obligation of the people in the BPMLC to send their children to school, encourage them to study and support them to go through primary, secondary and tertiary education. GSBPL's obligation is to engage, as much as possible, students for internship programmes, train them on the job and offer them jobs subject to availability of vacancies. The existing Golden Star Skills Training and Employability Programme (GSSTEP) now reflects as an offshoot of the LEA. The GSSTEP is tailored to equip the youth in BPMLC with skills to enable them become self-employed and/or employable. Participants are trained so that they can carry out mobile phone repairs, building electrical installation, commercial cooking, carpentry, masonry, etc. Upon completion, successful participants are provided with start-up tools to start their own business.

\subsection{The Development Foundation Agreement (DFA)}

The DFA sets out the modalities for the establishment and operation of a new development foundation known as the "Golden Star (Bogoso/Prestea) Ltd. Development Foundation (GSBPLDF)", which is a revised, documented version of the Golden Star Development Foundation (GSDF) that was used by the CDAM. The same amount of one dollar per ounce of gold produced and $0.1 \%$ of pre-tax profit is paid into the GSBPLDF to fund community development projects. However, unlike the GDF which allocated funds for projects selected from catchment areas, the GSBPLDF allocates available money to each catchment area using a sharing formula that takes into account the population, total land size in the mining lease, land size in the active mining area and commitment to the CSR Agreements of each catchment area (Mireku-Gyimah, 20120. Tables 6a and $6 \mathrm{~b}$ show how money is shared among the catchment areas. Each catchment area therefore knows its amount of money in any year and can select which development project is to be funded. The money for each catchment area may be small so it can take some years to complete a selected project but in this case the issue of unfair distribution is resolved. Two or more catchment areas can of course opt to use their combined money for one development project selected by them but because they opt to do so, they see it as their own choice and not an imposition by GSBPL. The GSBPLDF only recognises and provides funds for any of the following development projects agreed on by both Parties to be sustainable:

(i) Human resource development;

(ii) Infrastructure development;

(iii) Social amenities provision;

(iv) Natural resources protection; and

(v) Cultural heritage support.

Table 7 shows how the money of each catchment area is apportioned to the agreed sustainable development projects. Unlike the GSDF, which was managed by only GSBPL's personnel, the GSBPLDF has a Board of Trustees (BoT) comprising members from both Parties. Re- 
constituted $\mathrm{CCC}$ and $\mathrm{CMCC}$ continue to fulfill their respective mandates of evaluating and recommending development projects selected by any catchment area to the BoT, which is mandated to approve, and provide funds for, development projects.

\subsection{Successes and Challenges of the CSRAM}

Since its implementation in 2012, the CSRAM has been very successful. In particular, the CSR Agreements have:

(i) Strengthened the relation between the Parties;

(ii) Promoted peace and cooperation among the Parties;

(iii) Enhanced transparency and accountability in local employment procedures; (iv) Made the selection and funding of development projects transparent and acceptable;

(v) Instilled a sense shared ownership and responsibility among the Parties;

(vi) Facilitated the commissioning of the Prestea Underground Mine; and

(vii)Enabled the organisation of a public hearing on the Prestea South Mbease Nsuta Open Pit Project.

However, the CSRAM has generated the following challenges that need to be addressed through sensitisation education, monitoring and conflict resolution processes so that the full usefulness can be realised:

(i) Difficulty of enforcing compliance with the CSR Agreements; and

(ii) High demand for unavailable jobs.

Table 6a Weighting Factors for Sharing of Funds

\begin{tabular}{||c|c|c|c|c|c|c||}
\hline \multicolumn{1}{|c|}{ Criteria } & \multicolumn{2}{c|}{ Population } & \multicolumn{2}{c|}{ Mining Concession } & \multicolumn{2}{c||}{ Active Mining Area } \\
\hline $\begin{array}{c}\text { Catchment } \\
\text { Area }\end{array}$ & Size & Factor & Size & Factor & Size & Factor \\
\hline Prestea & 38390 & 0.46 & 6.36 & 0.03 & 1.05 & 0.015 \\
\hline Bogoso & 9819 & 0.12 & 43.62 & 0.22 & 19.03 & 0.274 \\
\hline Dumasi & 1571 & 0.02 & 18.7 & 0.10 & 12.12 & 0.175 \\
\hline Himan & 17074 & 0.21 & 19.8 & 0.10 & 9.19 & 0.133 \\
\hline Bondaye & 1923 & 0.02 & 26.87 & 0.14 & 7.07 & 0.102 \\
\hline Mbease Nsuta & 1262 & 0.02 & 37.47 & 0.19 & 7.78 & 0.112 \\
\hline Boppo & 6938 & 0.08 & 28.55 & 0.15 & 7.79 & 0.112 \\
\hline Ehyireso & 1892 & 0.02 & 4.15 & 0.02 & 0 & 0.000 \\
\hline Adamanso & 3784 & 0.05 & 9.15 & 0.05 & 5.31 & 0.077 \\
\hline Total & $\mathbf{8 2 ~ 6 5 3}$ & $\mathbf{1 . 0 0}$ & $\mathbf{1 9 4 . 6 7}$ & $\mathbf{1 . 0 0}$ & $\mathbf{6 9 . 3 4}$ & $\mathbf{1 . 0 0}$ \\
\hline
\end{tabular}

Table 6b Sharing of Funds (per \$100)

\begin{tabular}{||l|c|c|c|c|c|c||}
\hline \multicolumn{1}{|c|}{$\begin{array}{c}\text { Percentage } \\
\text { Catchment } \\
\text { Area }\end{array}$} & $\begin{array}{c}\mathbf{1 0 \%} \\
\text { Shared } \\
\text { Equally }\end{array}$ & $\begin{array}{c}\text { Shared by } \\
\text { Population }\end{array}$ & $\begin{array}{c}\text { Shared by } \\
\text { Concession }\end{array}$ & $\begin{array}{c}\text { Shared by } \\
\text { Activities }\end{array}$ & $\begin{array}{c}\text { Shared by } \\
\text { Commitment }\end{array}$ & Total \\
\hline Prestea & 1.11 & 6.97 & 0.65 & 0.61 & 1.67 & 11.00 \\
\hline Bogoso & 1.11 & 1.78 & 4.48 & 10.98 & 1.67 & 20.02 \\
\hline Dumasi & 1.11 & 0.29 & 1.92 & 6.99 & 1.67 & 11.98 \\
\hline Himan & 1.11 & 3.10 & 2.03 & 5.30 & 1.67 & 13.21 \\
\hline Bondaye & 1.11 & 0.35 & 2.76 & 4.08 & 1.67 & 9.97 \\
\hline Mbease Nsuta & 1.11 & 0.23 & 3.85 & 4.49 & 1.67 & 11.34 \\
\hline Boppoh & 1.11 & 1.26 & 2.93 & 4.49 & 1.67 & 11.46 \\
\hline Ehyireso & 1.11 & 0.34 & 0.43 & 0.00 & 1.67 & 3.55 \\
\hline Adamanso & 1.11 & 0.69 & 0.94 & 3.06 & 1.67 & 7.47 \\
\hline Total Amount & $\mathbf{1 0 . 0 0}$ & $\mathbf{1 5 . 0 0}$ & $\mathbf{2 0 . 0 0}$ & $\mathbf{4 0 . 0 0}$ & $\mathbf{1 5 . 0 0}$ & $\mathbf{1 0 0 . 0 0}$ \\
\hline
\end{tabular}


Table 7 Distribution among Development Projects

\begin{tabular}{|l|c|c|c|c|c|c|}
\hline $\begin{array}{c}\text { Development } \\
\text { Project }\end{array}$ & $\begin{array}{c}\text { Human } \\
\text { Resource Dev. } \\
\text { (HR) }\end{array}$ & $\begin{array}{c}\text { Infrastructure Dev. } \\
\text { (ID) }\end{array}$ & $\begin{array}{c}\text { Social } \\
\text { Amenities (SA) }\end{array}$ & $\begin{array}{c}\text { Natural } \\
\text { Resources } \\
\text { (NR) }\end{array}$ & $\begin{array}{c}\text { Cultural } \\
\text { Heritage } \\
\text { (CH) }\end{array}$ & $\begin{array}{c}\text { Total } \\
\mathbf{1 2 \%}\end{array}$ \\
\hline Catchment Area & $\mathbf{2 5 \%}$ & $\mathbf{3 0 \%}$ & $\mathbf{2 3 \%}$ & $\mathbf{1 0 0 \%}$ \\
\hline Prestea & 2.75 & 3.30 & 2.53 & 1.10 & 1.32 & 11.00 \\
\hline Bogoso & 5.00 & 6.01 & 4.60 & 2.00 & 2.40 & 20.02 \\
\hline Dumasi & 2.99 & 3.59 & 2.75 & 1.20 & 1.44 & 11.98 \\
\hline Himan & 3.30 & 3.96 & 3.04 & 1.32 & 1.59 & 13.21 \\
\hline Bondaye & 2.49 & 2.99 & 2.29 & 1.00 & 1.20 & 9.97 \\
\hline Mbease Nsuta & 2.84 & 3.40 & 2.61 & 1.13 & 1.36 & 11.34 \\
\hline Boppoh & 2.87 & 3.44 & 2.64 & 1.15 & 1.38 & 11.46 \\
\hline Ehyireso & 0.89 & 1.06 & 0.82 & 0.35 & 0.43 & 3.55 \\
\hline Adamanso & 1.87 & 2.24 & 1.72 & 0.75 & 0.90 & 7.47 \\
\hline Total Amount & $\mathbf{2 5 . 0 0}$ & $\mathbf{3 0 . 0 0}$ & $\mathbf{2 3 . 0 0}$ & $\mathbf{1 0 . 0 0}$ & $\mathbf{1 2 . 0 0}$ & $\mathbf{1 0 0 . 0 0}$ \\
\hline
\end{tabular}

\section{Conclusions}

In Ghana, mine local communities regard community development as the most important aspect of any CSR programme. Consequently, unless mining companies demonstrate commitment to clearly defined sustainable community development programmes, mine local communities would not be willing to cooperate or give the social license that mining companies need to operate peacefully.

Community development by Golden Star (Bogos/Pretea) Limited (GSBPL) within its mine local community, the Bogoso/Prestea Mine Local Community (BPMLC) has, over the years, gone through three evolutionary phases, each of which has a different model with its own strategies and action plans, videlicet from a poor Philanthropic Community Assistance Model (PCAM) to an improved but ineffective Community Driven Assistance Model (CDAM) and eventually to the current effective, successful CSR Agreements Model (CSRAM). Unlike the PCAM and the CDAM which lacked transparent documented guidelines, the CSRAM has three documented agreements resulting from deliberations, consultations and negotiations between GSBPL and the BPMLC: the Relationship and Alternative Livelihood Agreement (RALA); Local Employment agreement (LEA) and Development Foundation Agreement (DFA). These Agreements, respectively, regulate the relationship between GSBPL and the BPMLC; employment of people in the BPMLC by GSBPL; and socio-economic development of the BPMLC by GSBPL. The implementation of these agreements has promoted peaceful relation between, and instilled a sense of shared ownership and responsibility among, GSBPL and the BPMLC; enhanced transparency and accountability in the local employment procedures; and made the selection and funding of development projects transparent and acceptable. Public hearing on the Prestea South Mbease Nsuta Open Pit Project, which had hitherto faced social resistance and objection, has been organised successfully.

The experience of GSBPL clearly shows that mining companies need to shift from the earlier practices of making voluntary contributions towards community development to making community development an integral part the mining business. It is concluded that mutual understanding, tolerance, transparency, trust and commitment are key to successful management of CSR and community development.

\section{References}

Baker, M. (2010), “Corporate Social Responsibility - What does it mean?", http://www.mallenba ker.net/csr/definition.php, Accessed, April 2nd, 2014.

Davis, K. (1960), "Can Business Afford to Ignore its Social Responsibility?", California Management Review, pp. 70-76.

Ehsun, P. A., and Mireku-Gyimah, D. (2012), Economic Evaluation of Mineral Projects: A Socio-Environmental and Economic (SEE) Model for Gold Projects, Lambert Academic Publishing, Saarbrucken, 259 pp.

Freemen, R.E. and Liedtka, J. (1991), "Corporate Social Responsibility: A Critical Approach", Business Horizons, Vol. 4, pp. 92-98.

Gray, R., Owen, D. and Adams, C. (1996), Accounting and Accountability: Changes and Challenges in Corporate Social and Environmental Reporting, Prentice Hall, London, $344 \mathrm{pp}$.

Hamil, S. (1999), Corporate Community Involvement: A Case for Regulatory Reform", 
Business Ethics: A European Review, Vol. 8 (1), pp. 14-25.

Hilson, G. (2006), "Championing the Rhetoric? Corporate Social Responsibility in Ghana's Mining Sector", Greener Management International, Vol. 53, pp. 43-56.

Holme, 1. and Watts, R. (2000), Making Good Business Sense", http:www.docstoc.com/docs 1376600/making-good-sense, Accessed: April, 2, 2014.

Mireku-Gyimah, D. (2012), "Mining and Corporate Social Responsibility", Unpublished Presentation at the Mining Summit, Accra, 45 pp.

Wood, D. J. (1991), "Corporate Social Responsibility Revisited", Academy of Management Review, Vol. 16, pp. 691-718.

\section{Authors}

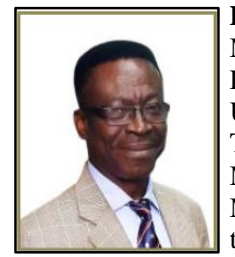

Mireku-Gyimah is a Professor of Mining Engineering and a Consulting Engineer currently working at the University of Mines and Technology, Tarkwa, Ghana. He holds the degrees of MSc from the Moscow Mining Institute, Moscow, Russia, and $\mathrm{PhD}$ and DIC from Technology and Medicine, London, $\mathrm{UK} . \mathrm{He}$ is a member of Institute of Materials, Minerals and Mining of UK and New York Academy of Sciences and also a fellow of Ghana Institution of Engineers and the Ghana Academy of Arts and Science. His research and consultancy works cover Mine Design and Planning, Mine Feasibility Study, Operations Research, Environmental Protection and Corporate Social Responsibility Management. He was the moderator and the architect of the CSR Agreements Model, the subject of this paper.

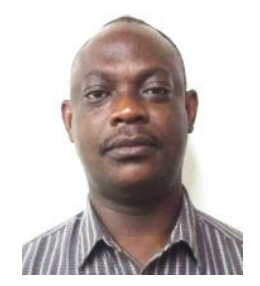

Robert Gyamfi is the Community Relations and Social Responsibility Manager of Golden Star (Bogoso/Prestea) Limited, (GSBPL), Ghana. Robert holds MBA (Oil and Gas Management) form the Robert Gordon University, Aberdeen, Scotland, MA (Developmental Studies.-.Agricultural and Rural Development) from the Institute of Social Studies, The Hague, Netherlands and BA (Integrated Development Studies) from the University of Development Studies, Tamale, Ghana. 